\title{
Methodological proposal for massive training of Ecuador's civil servants, in the educational field, through MOOC courses on Virtual Learning Environments
}

\author{
Lena Ivannova Ruiz Rojas \\ GRIAL Research Group, \\ Research Institute of Educational Sciences, \\ University of Salamanca \\ lenaruizr@gmail.com
}

\author{
Francisco J. García-Peñalvo \\ GRIAL Research Group, \\ Research Institute of Educational Sciences, \\ University of Salamanca \\ fgarcia@usal.es
}

\begin{abstract}
Being Ecuador a constitutional rule-of-law country [24] the formation of their leaders and their civil servants must be increasingly integral. Thereby, it is essential to incorporate computing updated training and development systems taking for granted that online training is becoming a very useful tool nowadays. This is complemented with the National Development Plan [24] which mentions that "education, understood the as development and training at different levels and cycles, is essential to strengthen and diversify the capacities and individual and social potentialities, to promote a participatory and critic citizenship" [27]. This research presents the results of a study carried out at the Universidad San Francisco de Quito, with the assistance of the Council for Higher Education to implement a methodology for massive training of Civil Servants of Ecuador in the context of education through a virtual course called "Virtual Learning Environments", which was issued at national level in Ecuador. In order to conduct this research, a guiding methodology was established to set up the content planning as well as the instructional design to obtain a virtual course structured in the MOOC platform requiring monitoring and evaluation of students and the technical and educational team as well. The sample consists of 310 teachers nationwide. The results are intended to establish the use of virtual learning environments by teachers who work at different universities in the country. In the case of this course, the current emphasis is placed on pre-production process being a key element in the success of MOOC. Therefore, the evaluation of quality starts from the very first steps. In this case, it refers to a MOOC that uses a Neuro-linguistic Programming base (NLP) and it will be screened by reverse instruction, assuming that the diagnostic of the initiating user's capabilities and skills is relevant to schedule the needed resources.
\end{abstract}

\section{CCS Concepts}

- Applied computing Computer-assisted instruction

\section{Keywords} MOOC; LMS; Learning Management System; xMOOC; cMOOC.

\section{INTRODUCTION}

The New York Times declared the year 2012 as the year of the MOOC (The Year of the MOOC) [22]. This is due to the extensive coverage this issue was given in the media and educational community in general $[4 ; 16 ; 19 ; 20]$. This wide diffusion of this new disruptive technology [23] has led to think that the MOOC is the most relevant technological innovation in education in the last 20 years [2].

The history of the term is prior to the use of the cooperative learning tool. Its meaning Massive Open Online Courses has been linked to the terms in Spanish (COMA (Cursos Online Masivos y Abiertos) or CALGE (Curso Abierto en Linea a Gran Escala). At the beginning, it was used by users with narrow and specific profiles, but since 2012, it has become more popular and used by larger number of people.

In recent years, learning processes have incorporated different approaches based on technology to a greater or lesser extent, which include the LMS (Learning Management System) [28; 29] social and cooperative learning, and lately the phenomenon of MOOC courses, where it is necessary to include learning analytics to collect and analyze data that can allow to assess learning in the context of these massive courses $[13 ; 17]$. Currently, several educational institutions and international organizations have joined and work together, especially on topics related to MOOC.

The MOOC notion, in its short period of development, has experienced a division that distinguishes xMOOC from cMOOC [8-10; 12]. The first one has a formal structure, based on the development of tasks and has a process of peer support as an alternative to traditional tutoring; meanwhile, the cMOOC is based on connectivity, which is implemented through relationships between nodes (people) who are contributing and interacting with content and messages through a platform.

Like everything else, there are positive and negative aspects of the MOOC which are described below.

One of the main advantages of MOOC is the cost of such training for the person who follows it as it is generally lower than other modalities, with the particularity that if a person wants certification, he must pay for it. One of the biggest differences with the common eLearning courses is the massiveness that MOOC has [26]. 
One of the disadvantages of the MOOC worth mentioning is that there is no continuous monitoring, as there is in common eLearning courses; there is a technical and pedagogical group made up of a dynamic team that provide feedback to forums, mass comments and technical problems, which does not happen in training tutoring online which has professional's assistance, always attentive to our progress in the course matter. For many people, this lack of "rules" or "obligations" ends with the abandonment of a course [1].

At present, the new educational trends as MOOC, double layer mastery, online courses and others are part of different instructional design methodologies oriented or aimed at developing activities with guidelines as the PLE (Personal Learning Environment) [5; 6; 31], which describes in detail how to combine conventional activities with the help of technological tools, using appropriate mechanism for raising activities and use 2.0 web tools [25].

This research is framed in a context of constant development towards a society of knowledge, objective Ecuador pursues from the conception of state strategic plans to its philosophy of "buen vivir" (good living) [27]. In this context of constant upward development, the exercise of responsible research that frames real situations is impelled and that real and viable solutions be proposed to frame the common well and result in benefits to the Ecuadorian people.

The Regulations of the Academic Regime issued on 12 November 2013 by the Council of Higher Education, establishes the modes of study and learning (Chapter VI, Article 38), as well as the organization of learning (Chapter II, Article 15) and constitutes the legal base that covers different ways of incorporating technological tools to university teaching.

Even though it is true, the current Ecuadorian government has made remarkable achievements in public infrastructure and the implementation of social policies, it is essential to continue investing in human talent. It is considered that one of the main problems of Ecuador's education is the lack of methodologies for the construction and development of a MOOC to strengthen training and ongoing training. The MOOC can offer the way to acquire new and different job skills [14].

Another problem is the need for education and training faced by a large number of public servants all over the country. Hence to use the MOOC methodology is no longer an option but it has become a necessity that will optimize the financial and human resources [7; 15; 18].

MOOC does not differ from more traditional online courses. Fidalgo et al. [11] indicate that the teaching methodology for MOOC must have the following: video lessons, quizzes, homework, tests, and forums.

The evaluation can be performed by various methods and is of two types. The first one is the evaluation of content which allows knowing whether the teaching objective of the course or the learning of any particular content or the formation of certain skills or competencies have been achieved [26]. The second one is the course evaluation which assesses whether the expectations were met, if those who enrolled continued to the end and if not why. Furthermore, processes, materials, structures and other [26] are evaluated.

After the evaluation process is finished, the correction of those aspects that are correctable and have been detected in the process of teaching the MOOC proceeds. To avoid making the same mistakes over and over again is now essential [26].

To this end, a methodology for massive training of Civil Servants of Ecuador in the context of the educational field was developed. This research is intended to contribute to the analysis of technological and educational factors, so that it meets the quality indicators a virtual course has.

Two sections containing the methodology, tools, results of descriptive analysis, and finally, the most important conclusions derived from the study are presented.

\section{METHODOLOGY}

This research is based on a mixed quantitative and qualitative methodology, which seeks to ensure the effectiveness and rigor required for optimal research design and to obtain the views of those involved in the process of teaching and learning in order to improve the process [3].

The proposed methodology is mainly based on integrating principles embraced by (socio-constructivist and connectivity), with emphasis on active, autonomous and cooperative student's role in global society. It aims to create collective knowledge and to apply it to academic and professional problems as well as to communicate it properly. Thereby, participants become protagonists of their own educational process involving them in situations of open learning and reflective inquiry. In addition, the cognitive theory is implicit [3].

This paper has a component of applied evaluation research because it is complemented by an evaluation process. The descriptive method is the applied method based on a case study of institutional mass training.

Stake [30] presents a case study method in which it is essential to develop questions that guide the investigation into the case study which is particularly unique but it can also reproduce a dynamic present in other cases that might be analyzed in the future. The answer to these questions will not only guide the work but establish a framework assessment case study. The author emphasizes the qualitative view of this type of study where the arguments, qualities of the case, causes and effects of the situation studied, are essential.

In addition to the above information, Stake [30] emphasizes the observation which, together with the research questions, might guide the process towards the concluding ideas. Thereby, the parts of the information collecting are: "case definition, the list of research questions, identifying assistants, data sources, distribution of time, foreseen expenses and reports" (p. 53) Thus, the established process for the case study requires the following steps: anticipation, first visit, preparation for observation, other activities and conceptualizations, data collection, data validation, results analysis, trying to ease its understanding (p. 54).

From the theoretical point of view the following methods are used: 
- Historical and logical: in addressing the problem from the universal to the particular, from the abstract to the concrete. It is a method of thought which encourages the understanding of the processes, causes and effects, in social, cultural, groups and individuals [14].

- Analytic-synthetic: present throughout the investigation involving the analysis of the subject matter to later confront the synthesis of the main ideas either theoretically and empirically.

- In the empirical area: literature and document review is used: searching of backgrounds, experiences and the most important theories related to the topic [3].

- The interview. This is an instrument which complements the literature review since it is part of the searching being empyrean or actual practice of some specialists involved in the issue [3].

The methodology of data collection was applied in the learning process of the course, in addition to a qualitative study of the proposed methodology. It was carried out with the application of various techniques for collecting information to the selected sample of users of the training program in MOOC. It was used as reference:

- Questionnaire context where information on the type of user of the MOOC platform intervening variables (personal and contextual) was collected. As far as possible, their validity was assessed by expert judgment.

- A quiz applied to users about usability LMS and content quality, which was applied and validated at the Tecnológico de Monterrey. This questionnaire would be modified to suit the virtual learning environment of USFQ with prior validation.

- A users satisfaction survey about the training process verifying reliability (internal consistency).

This work seeks to show confidence in the results, therefore the authenticity of the data and selection of instruments would be established through processes of internal validity and reliability, operational definition of the variables and standardized sample, to give credibility to the investigation process.

\subsection{Collecting Information Instrument}

Complementing the research development related to the progress of the mass course, a questionnaire was used, as a common technique in educational research [21], considering it a necessary tool to collect the information needed for this first quantitative study.

Furthermore, the following parameters were applied for the development of the course:

The first one would be assessed through a survey applied to public servants, to know their profile, age, gender, nationality and experience at using MOOC, degree of knowledge in course management.

The second one would be evaluated through a survey applied to public servants, being evaluated: the usability of the LMS platform, level of interactivity and interface management.

The third one would be evaluated through a survey applied to public servants measuring the degree of quality of content and evaluation of virtual classes.

The fourth one would be assessed through a survey applied to public servants regarding the course satisfaction.

As mentioned in the methodology, it was necessary to develop and validate a questionnaire as the main tool for collecting information; expecting as well to provide a reliable measuring instrument to the scientific community.

\section{RESULTS}

We begin with the analysis of some representative variables using the following tables.

The methodology of data collection was applied in the learning process of the course, in addition to qualitative study of the proposed methodology; it was carried out with the application of various techniques various techniques for gathering information on the selected sample.

As reference, it was used: a context questionnaire to collect information of the type of user of the MOOC platform about intervening variables (personal and contextual), to know their profile, age, gender, nationality and experience with MOOC and degree of knowledge in MOOC course management. 
Table 1. Total participation in a MOOC course: virtual learning environments

\begin{tabular}{|l|c|c|}
\hline Row Labels & Percentage & $\begin{array}{c}\text { Have you } \\
\text { participated } \\
\text { before in a } \\
\text { massive open } \\
\text { online MOOC } \\
\text { course? }\end{array}$ \\
\hline No answer & $4.3 \%$ & 8 \\
\hline $\begin{array}{l}\text { I have participated in } \\
\text { more than 10 massive } \\
\text { open online courses }\end{array}$ & $2.6 \%$ & 49 \\
\hline $\begin{array}{l}\text { I have participated in } \\
\text { more than 2 massive } \\
\text { open online courses }\end{array}$ & $15.8 \%$ & 16 \\
\hline $\begin{array}{l}\text { I have participated in } \\
\text { more than 5 massive } \\
\text { open online courses }\end{array}$ & $5.2 \%$ & 88 \\
\hline $\begin{array}{l}\text { I have participated in } \\
\text { one massive open online } \\
\text { course }\end{array}$ & $28.4 \%$ & 145 \\
\hline $\begin{array}{l}\text { I have not attended a } \\
\text { course before }\end{array}$ & $46.8 \%$ & $\mathbf{3 1 0}$ \\
\hline Total & $100.0 \%$ & \\
\hline
\end{tabular}

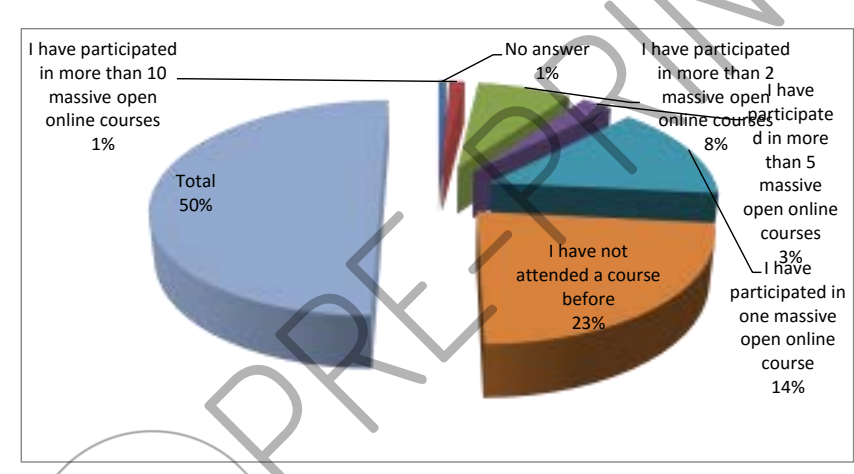

Figure 1. Percentage of the of participation level in a MOOC course: virtual learning environments

Figure 1 shows that from the 310 participants, $46.8 \%$ are unaware of the learning massive management system, called MOOC.

Table 2. Total participation in a MOOC course: virtual learning environments, for female and male gender

\begin{tabular}{|l|l|c|}
\hline Row Labels & $\begin{array}{l}\text { Have you } \\
\text { participated before } \\
\text { in a massive open } \\
\text { online MOOC } \\
\text { course? } \\
\text { FEMALE }\end{array}$ & $\begin{array}{c}\text { Have you } \\
\text { participated } \\
\text { before in a } \\
\text { massive open } \\
\text { online } \\
\text { MOOC } \\
\text { course? } \\
\text { MALE }\end{array}$ \\
\hline No answer & 1 & 1 \\
\hline $\begin{array}{l}\text { I have participated in more } \\
\text { than 10 massive open } \\
\text { online courses }\end{array}$ & 5 & 3 \\
\hline $\begin{array}{l}\text { I have participated in more } \\
\text { than 2 massive open online } \\
\text { courses }\end{array}$ & 27 & 22 \\
\hline $\begin{array}{l}\text { I have participated in more } \\
\text { than 5 massive open online } \\
\text { courses }\end{array}$ & & \\
\hline
\end{tabular}




\begin{tabular}{|l|c|c|}
\hline $\begin{array}{l}\text { I have participated in one } \\
\text { massive open online course }\end{array}$ & 40 & 48 \\
\hline $\begin{array}{l}\text { I have not attended a } \\
\text { course before }\end{array}$ & 83 & 64 \\
\hline Total & $\mathbf{1 6 0}$ & $\mathbf{1 5 0}$ \\
\hline Percentage & $\mathbf{5 1 . 6 \%}$ & $\mathbf{4 8 . 4 \%}$ \\
\hline
\end{tabular}

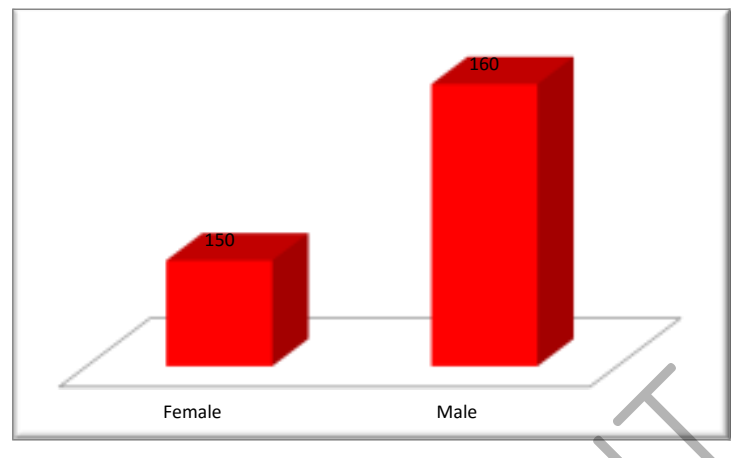

Figure 2. Total participation in a MOOC course: virtual learning environments, for female and male gender

From a total of 310 participants, Figure 2 shows that there is gender equality, female $51.6 \%$ and male $48.4 \%$.

Table 3. Number of teachers who participated in the course per university, Salesian University, Catholic University of Ecuador, National Polytechnic School

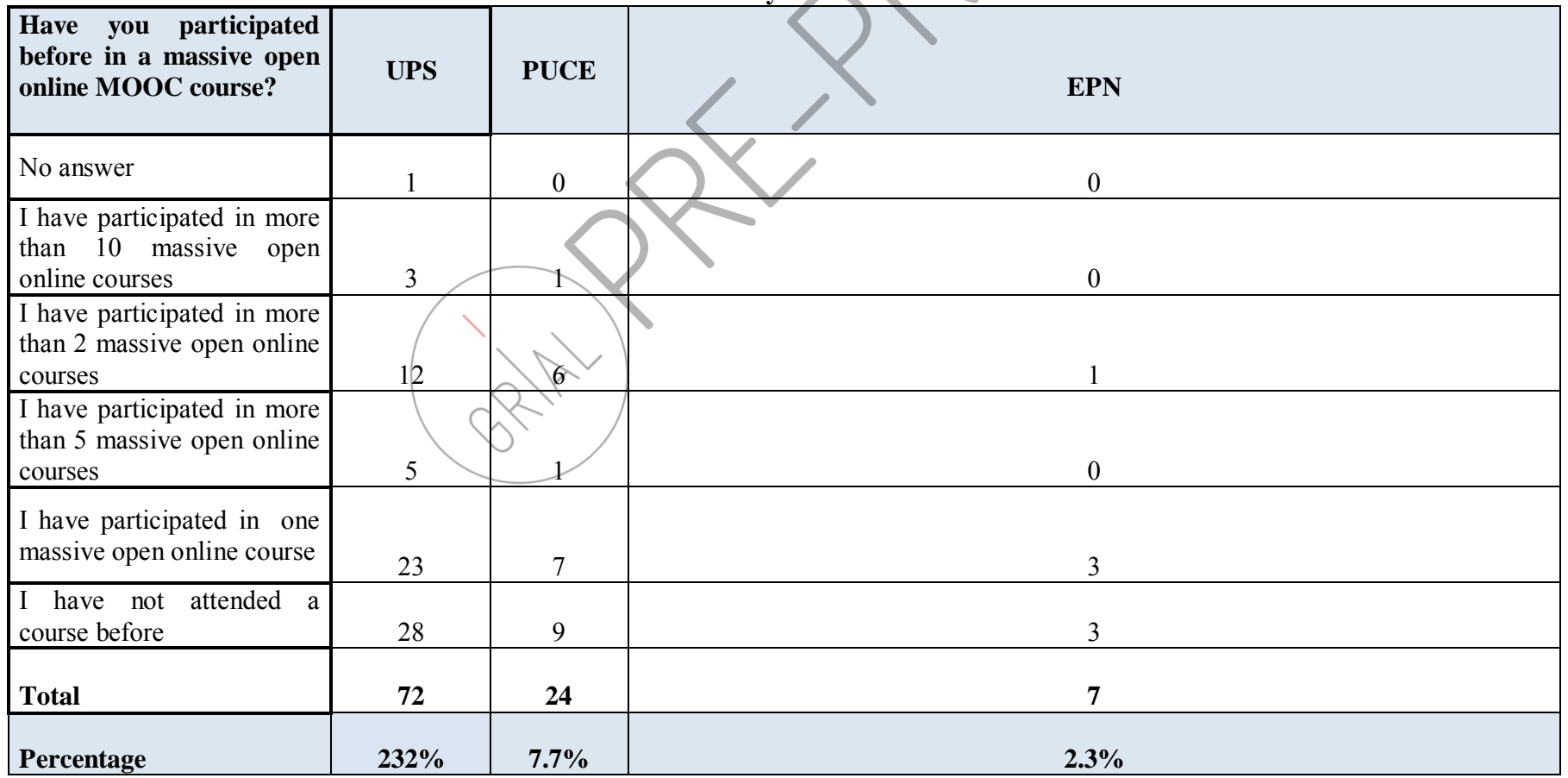




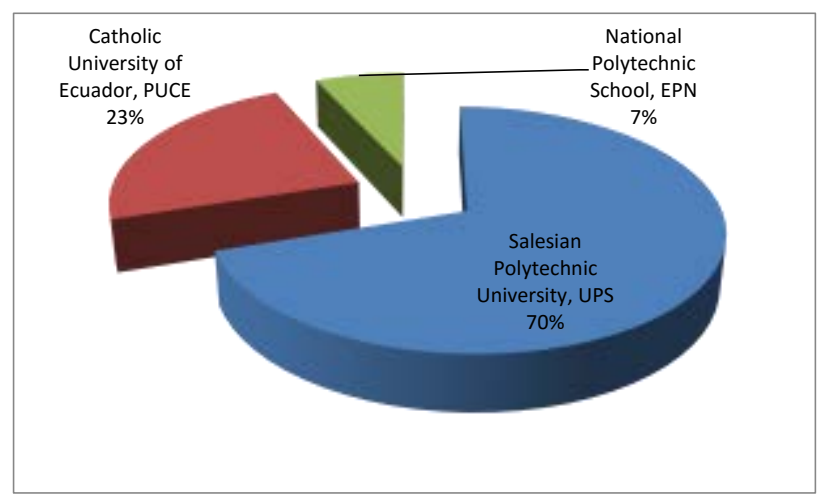

Figure 3. Total Universities that took part in the MOOC course: virtual learning environments

Table 3 and Figure 3 reflect in detail the participation of the Salesian University, Catholic University and National Polytechnic School.

Next, the educational institutions that participated nationwide are stated: Universidad Técnica del Norte, Instituto San Isidro, CuencaEcuador, Ministerio de Educación, Escuela Superior Politécnica Agropecuaria de Manabí ESPAM MFL, Instituto Tecnológico Superior Nuestra Señora del Rosario, Catamayo, Loja, Ecuador, Universidad Técnica de Manabí, Colegio Seis de Diciembre, Universidad Estatal del Sur de Manabí, Unidad Educativa Lev Vygotsky - Sangolquí, Universidad Tecnológica Equinoccial, Universidad Laica Eloy Alfaro de Manabí, Universidad Estatal Amazónica, Unidad Educativa "Santo Domingo de Guzmán " Ambato, Senescyt - Instituto Tecnológico Superior Aloasí, Yachay EP, Universidad Internacional, Universidad de Cuenca, UTE, Universidad Técnica de Cotopaxi, Unidad Educativa Augusto Nicolás Martínez, Unidad Educativa "Pedro Fermín Cevallos" - Cevallos - Tungurahua, Armada del Ecuador, Universidad Tecnológica Equinoccial, Unidad Educativa San Gerardo, Universidad Estatal Amazónica, Universidad Internacional Del Ecuador, Unidad Educativa "Atahualpa", Unidad Educativa Daniel Álvarez Burneo, Loja, Universidad Central del Ecuador, Universidad Técnica de Machala, Unidad Educativa Inés Cobo Donoso Pujilí - Cotopaxi, Instituto Tecnológico Superior Guayaquil, Colegio Alberto Einstein, Unidad Educativa "Ibarra", USFQ.

Table 4. Usefulness of the platform

\begin{tabular}{|l|c|c|}
\hline Row Labels & Percentage & $\begin{array}{c}\text { The use of the } \\
\text { technological platform } \\
\text { is reliable as there are } \\
\text { no technical failures }\end{array}$ \\
\hline 1 Totally disagree & $3.9 \%$ & 12 \\
\hline 2 Disagree & $9.7 \%$ & 30 \\
\hline 3 Neither agree nor disagree & $13.2 \%$ & 41 \\
\hline 4 Agree & $37.4 \%$ & 116 \\
\hline 5 Totally agree & $24.5 \%$ & 76 \\
\hline Defection of participants & $11.3 \%$ & 35 \\
\hline Total & $100.0 \%$ & $\mathbf{3 1 0}$ \\
\hline
\end{tabular}

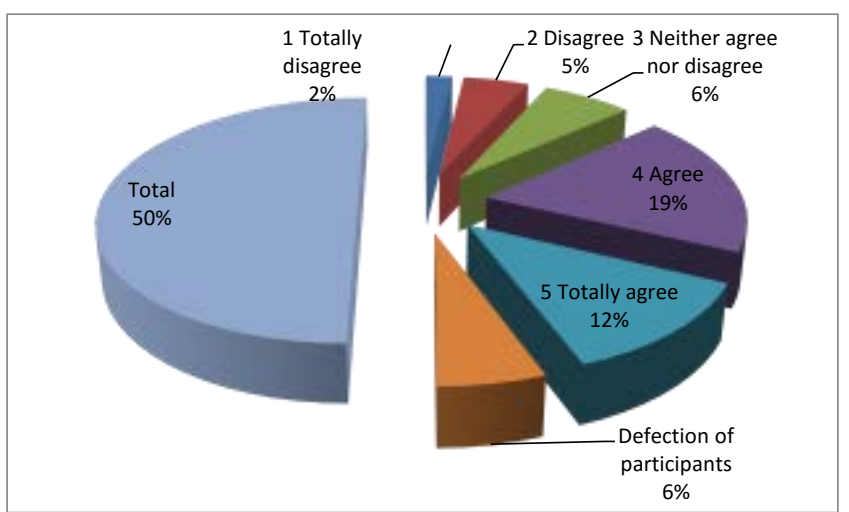

Figure 4. Usefulness of the platform 
Table 5. Navigating the LMS

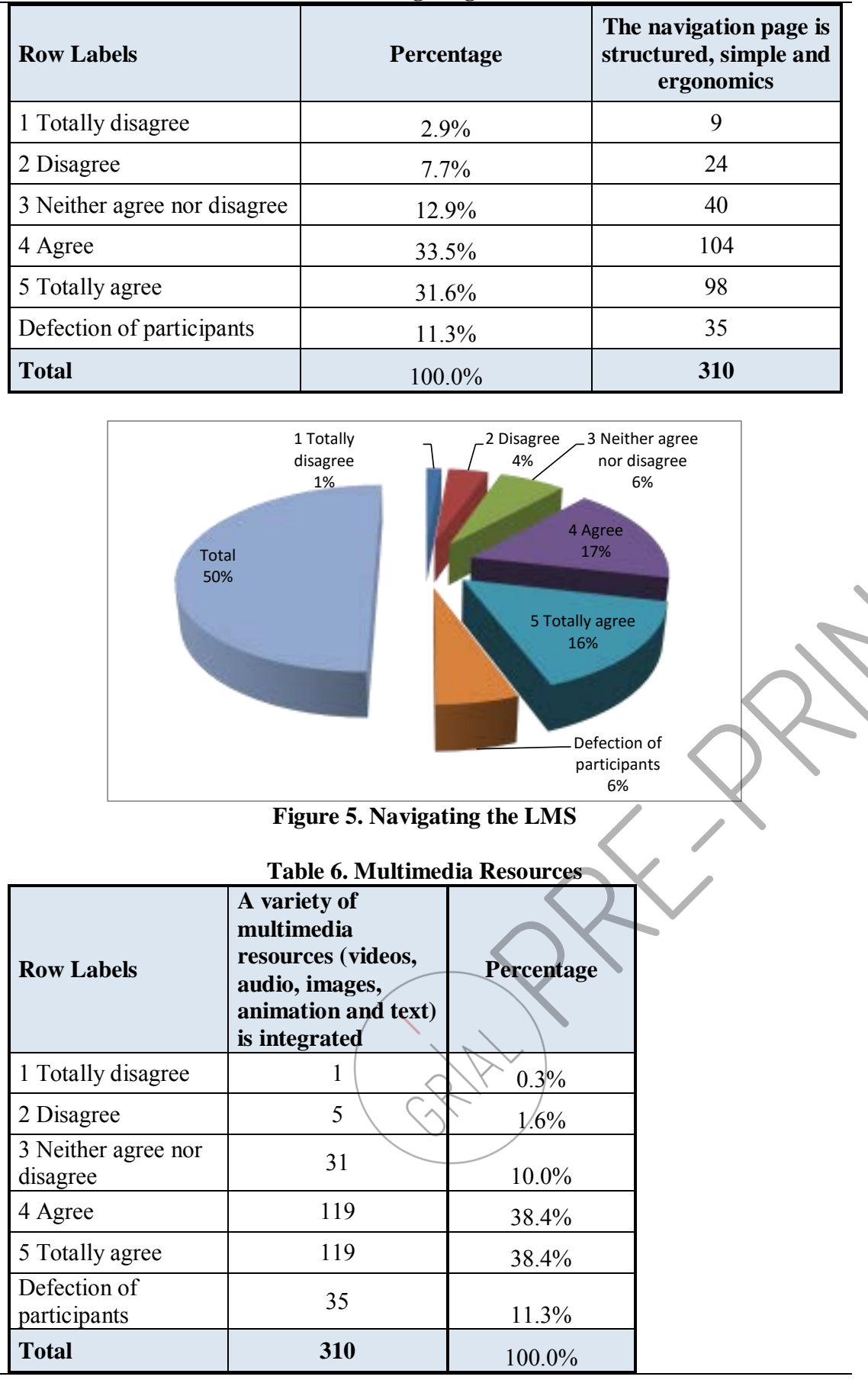




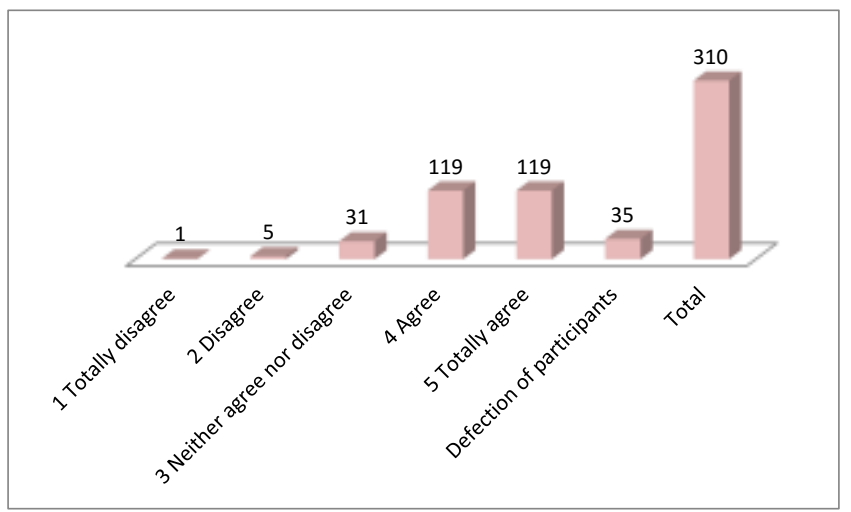

Figure 6. Multimedia Resources

Table7. Interface

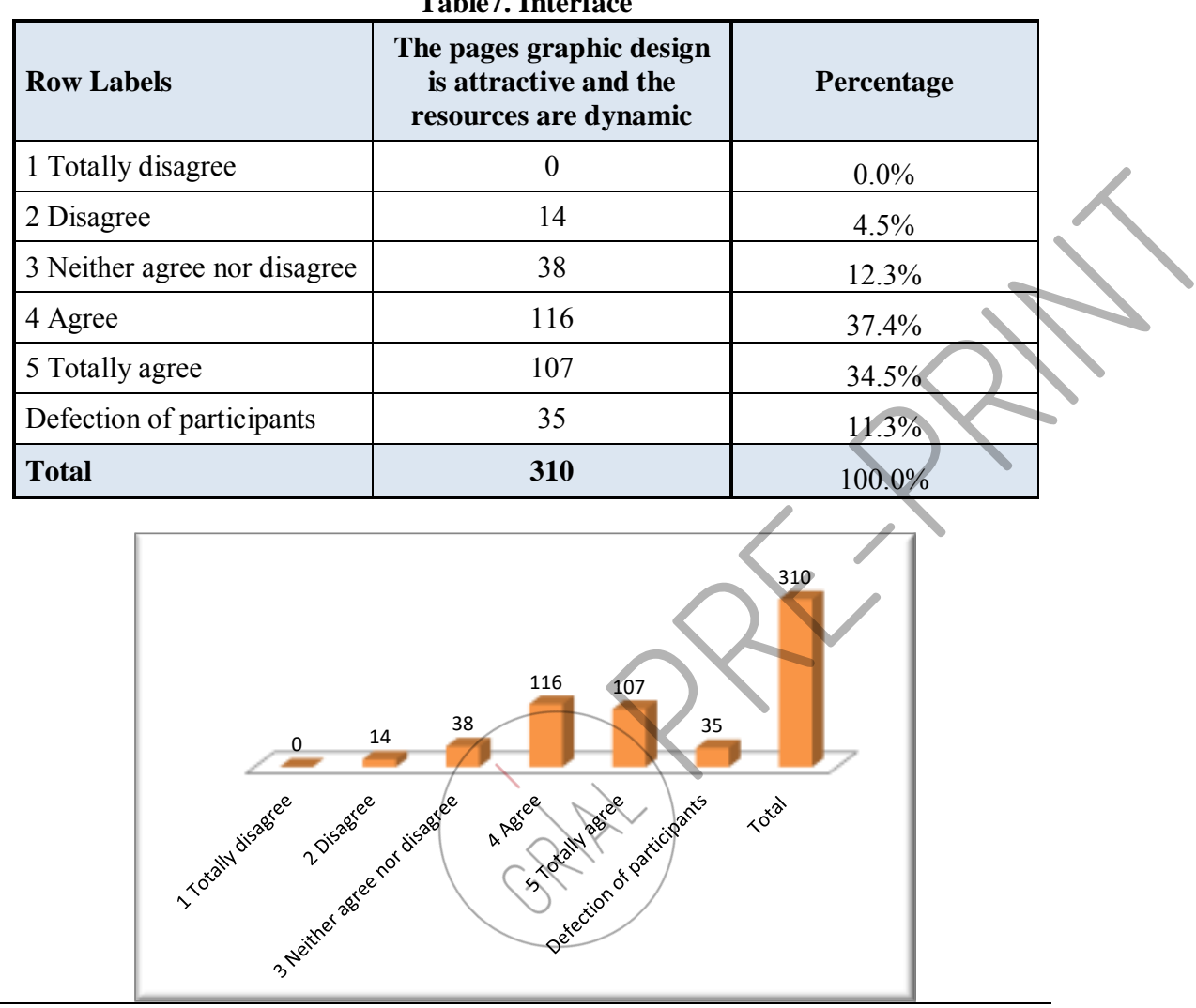

Figure7. Interface

From a total of 310 participants, Tables 5, 6 and 7, reflect how the usefulness of the LMS platform was evaluated obtaining over a $61.9 \%$ satisfaction. The navigation on pages is structured, simple and ergonomics. The attitude and degree of motivation before the use of the LMS has $76.8 \%$ of acceptance and the level of access to the platform level, interactivity, management interface, has $71.9 \%$ acceptance as well. Thus, it is verified that the technological component meets the quality indicators of a virtual course.

Tables 8, 9 and 10 reflect how the course was evaluated, the level of quality of content and evaluation of virtual classes, showing an $78.4 \%$ acceptance, reflecting the evaluation meets the quality indicators of the pedagogical component. 
Table 8. Agenda: planning activities

\begin{tabular}{|c|c|c|}
\hline Row Labels & $\begin{array}{l}\text { The calendar helps you } \\
\text { plan the time to be } \\
\text { devoted to the course }\end{array}$ & Percentage \\
\hline 1 Totally disagree & 5 & $1.6 \%$ \\
\hline 2 Disagree & 18 & $5.8 \%$ \\
\hline 3 Neither agree nor disagree & 33 & $10.6 \%$ \\
\hline 4 Agree & 106 & $34.2 \%$ \\
\hline 5 Totally agree & 113 & $36.5 \%$ \\
\hline Defection of participants & 35 & $11.3 \%$ \\
\hline Total & 310 & $100.0 \%$ \\
\hline
\end{tabular}

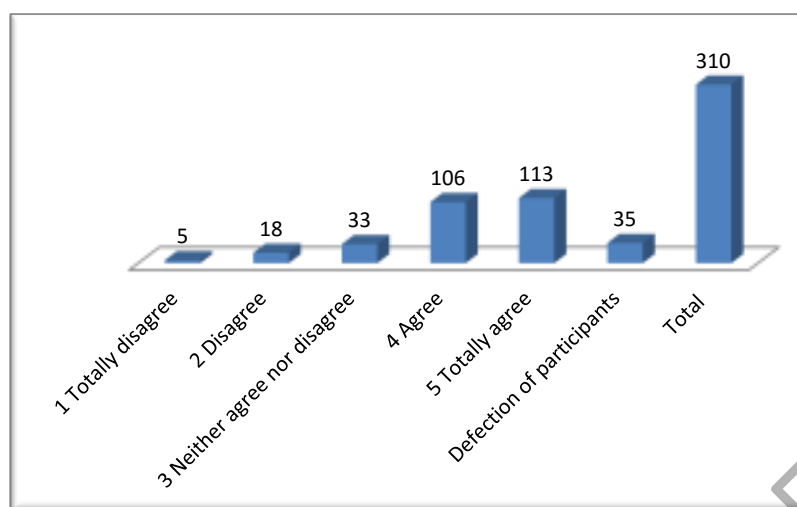

Figure 8. Agenda: planning activities

Table 9. Content structure

\begin{tabular}{|l|c|c|}
\hline \multicolumn{1}{|c|}{ Row Labels } & $\begin{array}{c}\text { The topics are well } \\
\text { structured and have a } \\
\text { logical order }\end{array}$ & Percentage \\
\hline 1 Totally disagree & 3 & $1.0 \%$ \\
\hline 2 Disagree & 5 & $1.6 \%$ \\
\hline 3 Neither agree nor disagree & 24 & $7.7 \%$ \\
\hline 4 Agree & 116 & $37.4 \%$ \\
\hline 5 Totally agree & 127 & $41.0 \%$ \\
\hline Defection of participants & 35 & $11.3 \%$ \\
\hline Total & $\mathbf{3 1 0}$ & $100.0 \%$ \\
\hline
\end{tabular}




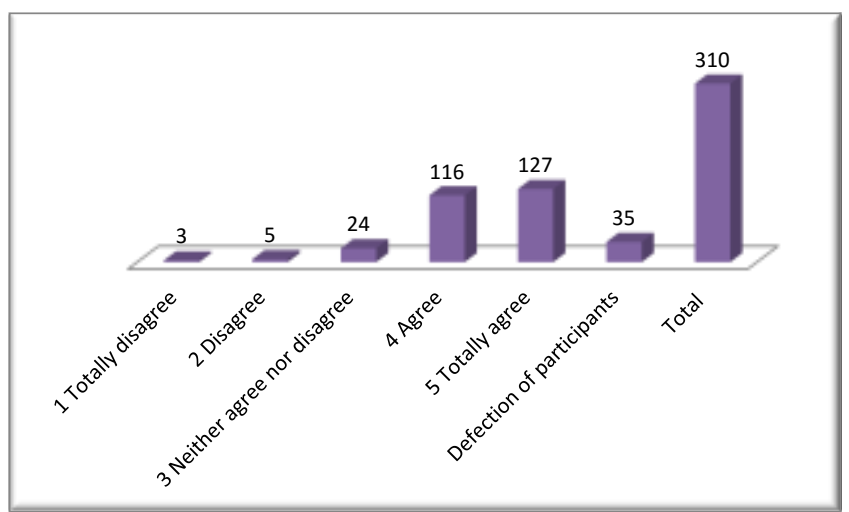

Figure 9. Content structure

Table 10. Achievement of the objectives

\begin{tabular}{|l|c|c|}
\hline \multicolumn{1}{|c|}{ Row Labels } & $\begin{array}{c}\text { The activities and } \\
\text { exercises focus on } \\
\text { the achievement of } \\
\text { the unit objectives }\end{array}$ & Percentage \\
\hline 1 Totally disagree & 2 & $0.6 \%$ \\
\hline 2 Disagree & 2 & $0.6 \%$ \\
\hline $\begin{array}{l}\text { 3 Neither agree nor } \\
\text { disagree }\end{array}$ & 27 & $8.7 \%$ \\
\hline 4 Agree & 128 & $41.3 \%$ \\
\hline 5 Totally agree & 116 & $37.4 \%$ \\
\hline $\begin{array}{l}\text { Defection of } \\
\text { participants }\end{array}$ & 35 & $11.3 \%$ \\
\hline \multicolumn{1}{|c|}{ Total } & $\mathbf{3 1 0}$ & $100.0 \%$ \\
\hline
\end{tabular}

Table 11 and Figure 11 reflect through a questionnaire, the users' satisfaction for the course, to the training process, showing a $76.1 \%$ (agree $34.5 \%$ and totally agree $41.6 \%$ ) of approval.

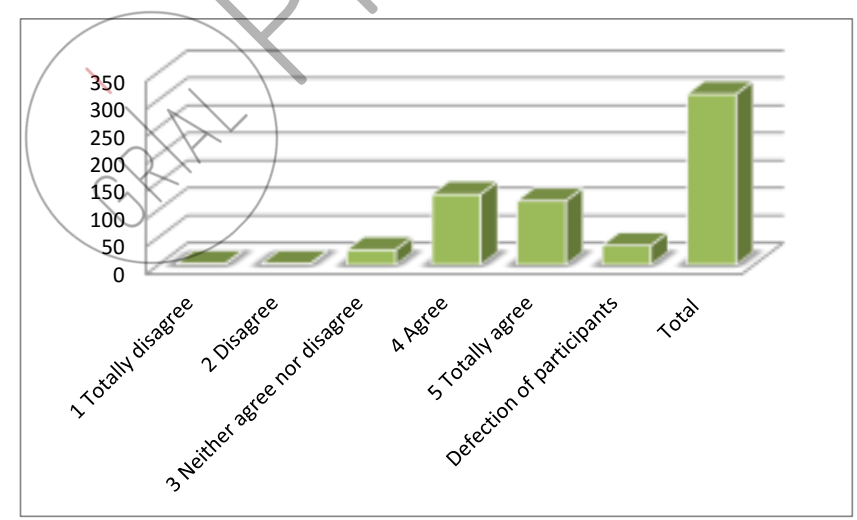

Figure 10. Achievement of the objectives 
Table 11. Satisfaction of the course

\begin{tabular}{|l|c|c|}
\hline Row Labels & $\begin{array}{l}\text { The course has benefited } \\
\text { me professionally }\end{array}$ & Percentage \\
\hline 1 Totally disagree & 5 & $1.6 \%$ \\
\hline 2 Disagree & 5 & $1.6 \%$ \\
\hline 3 Neither agree nor disagree & 29 & $9.4 \%$ \\
\hline 4 Agree & 107 & $34.5 \%$ \\
\hline 5 Totally agree & 129 & $41.6 \%$ \\
\hline Defection of participants & 35 & $11.3 \%$ \\
\hline Total & $\mathbf{3 1 0}$ & $100.0 \%$ \\
\hline
\end{tabular}

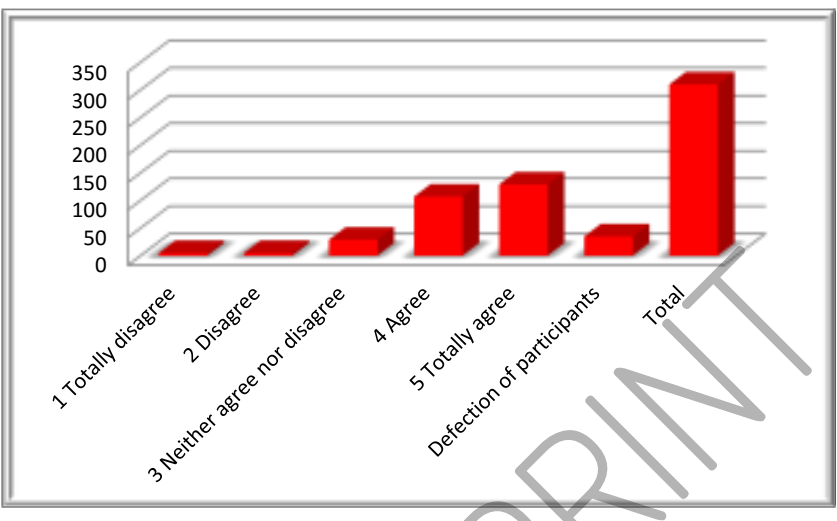

Figure 11. Satisfaction of the course

\section{CONCLUSIONS}

The obtained results in this study allow us to conclude that teachers have a favorable disposition toward the use of systems of mass management to implement it in their teaching professorship, even though $46.8 \%$ of participants are unaware of massive learning management systems called MOOC; it also reflects that there is gender equity, $51.6 \%$ female and $48.4 \%$ male and participation in the course has been varied from different educational institutions all over the country, reflecting the interest in updating their knowledge to improve their professional profile.

Regarding the usefulness of the LMS platform, more than $61.9 \%$ (agree $37.4 \%$ and totally agree $24.5 \%$ ) say that the use of the technological platform is reliable because no technical failure showed up. As in any massive process of training, the first week is for coupling to the environment and there's a slight defection of participants: Tables 5, 6 and 7 show that the defection of participants was minimal $11.3 \%$.

The quality of contents as well as the evaluation of virtual classes, based on the questions raised, was verified having the quality indicators such as: tutorial or didactic guide to measure the clarity of the aims of the course, the statement of objectives and reinforcement activities; the methodology that measures the adequacy of the contents to the objectives, the methodological consistency and coherence of enforcement activities; the organization of content: the structure of content, quality of content: evaluating rubrics, teaching resources: related to the versatility of the course to teach the content in different ways; multimedia elements related to multimedia and graphic quality of the course and its resources; and, style of language that analyze the syntax and semantics of the contents.

In conclusion, the usage of technical and methodological resources used in the LMS, allows teachers to practice what was learned in the academic field i.e. the use of academic forums, simulators and interactive activities provoking meaningful learning.

For future studies, it would be interesting to note that this methodology works in other areas of knowledge, so that its versatility and flexibility can be verified.

It is also worth mentioning that, in the light of the results, it would be beneficial to design innovative new courses with educational initiatives that highlight the potential for achieving meaningful learning.

This opens the door for further studies of new training methodology and development in different areas of knowledge.

\section{ACKNOWLEDGMENTS}

This research was conducted at the Universidad San Francisco de Quito, with the support of Council of Higher Education of Ecuador. 


\section{REFERENCES}

[1] Arias Masa, J., 2007. Evaluación de la calidad de Cursos Virtuales: Indicadores de Calidad y construcción de un cuestionario de medida. Aplicación al ámbito de asignaturas de Ingeniería Telemática. In Departamento de Didáctica de las Ciencias Experimentales y de las Matemáticas Universidad de Extremadura, Mérida, España.

[2] Armstrong, L., 2014. Title. In Changing Higher Education, http://goo.gl/SqwGWn.

[3] Badilla Cavaría, L., 2006. Fundamentos del paradigma cualitativo. Revista de Ciencias del Ejercicio y la Salud 4, 1, $42-51$.

[4] Chiappe Laverde, A., Hine, N., and Martínez Silva, J.A., 2015. Literatura y práctica: una revisión crítica acerca de los MOOC. Comunicar 44, 09-18. DOI= http://dx.doi.org/http://dx.doi.org/10.3916/C44-2015-01.

[5] Conde, M.Á., García-Peñalvo, F.J., Casany, M.J., and Alier Forment, M., 2013. Personal Learning Environments and the Integration with Learning Management Systems. In Information Systems, E-learning, and Knowledge Management Research. 4th World Summit on the Knowledge Society, WSKS 2011, Mykonos, Greece, September 21-23, 2011. Revised Selected Papers, M.D. Lytras, D. Ruan, R. Tennyson, P. Ordoñez De Pablos, F.J. García- Peñalvo and L. Rusu Eds. Springer Verlag, Berlin, Heidelberg, 16-21. DOI= http://dx.doi.org/10.1007/978-3-642-35879-1_3.

[6] Conde, M.Á., García-Peñalvo, F.J., Rodríguez-Conde, M.J., Alier, M., Casany, M.J., and Piguillem, J., 2014. An evolving Learning Management System for new educational environments using 2.0 tools. Interactive Learning Environments 22, 2, 188-204. DOI= http://dx.doi.org/10.1080/10494820.2012.745433.

[7] Dalmau, Ó., Herrero García, O., Mas Crespo, G., Pérez, F., Riera, C., Rubio Carbó, A., Alós, M., Casamayor Pérez, G., and Chiné, M., 2011. La formación on-line: Una mirada integral sobre el e-learning, b-learning... . Graó, Madrid, España.

[8] Daniel, J., 2012. Making Sense of MOOCs: Musings in a Maze of Myth, Paradox and Possibility. Journal of Interactive Media in Education 2012, 3.

[9] Fidalgo-Blanco, Á., García-Peñalvo, F.J., and Sein-Echaluce Lacleta, M.L., 2013. A methodology proposal for developing adaptive cMOOC. In Proceedings of the First International Conference on Technological Ecosystems for Enhancing Multiculturality (TEEM'13), F.J. García-Peñalvo Ed. ACM, New York, NY, USA, 553-558. DOI= http://dx.doi.org/http://dx.doi.org/10.1145/2536536.2536621.

[10] Fidalgo-Blanco, Á., Sein-Echaluce Lacleta, M.L., and García-Peñalvo, F.J., 2013. MOOC cooperativo. Una integración entre cMOOC y xMOOC. In Actas del II Congreso Internacional sobre Aprendizaje, Innovación y Competitividad (CINAIC), Á. Fidalgo Blanco and M.L. Sein-Echaluce Lacleta Eds. Fundación General de la Universidad Politécnica de Madrid, Madrid, Spain, 481-486.

[11] Fidalgo-Blanco, Á., Sein-Echaluce Lacleta, M.L., and García-Peñalvo, F.J., 2015. Methodological Approach and Technological Framework to break the current limitations of MOOC model. Journal of Universal Computer Science 21, 5, 712-734. DOI= http://dx.doi.org/10.3217/jucs-021-05-0712.

[12] Fidalgo-Blanco, Á., Sein-Echaluce, M.L., and García-Peñalvo, F.J., 2016. From massive access to cooperation: Lessons learned and proven results of a hybrid xMOOC/cMOOC pedagogical approach to MOOCs. International Journal of Educational Technology in Higher Education (ETHE) 13, 24. DOI= http://dx.doi.org/10.1186/s41239-016-0024-z.

[13] Fidalgo-Blanco, Á., Sein-Echaluce, M.L., García-Peñalvo, F.J., and Conde, M.Á., 2015. Using Learning Analytics to improve teamwork assessment. Computers in Human Behavior 47, 149-156. http://dx.doi.org/http://dx.doi.org/10.1016/j.chb,2014.11.050.

[14] Fundación Telefónica, 2015. Los MOOC en la educación del futuro: La digitalización de la formación. Ariel, Barcelona, España.

[15] García-Peñalvo, F.J., 2015. Cómo entender el concepto de presencialidad en los procesos educativos en el siglo XXI. Education in the Knowledge Society (EKS) 16,2, 6-12. DOI= http://dx.doi.org/ http://dx.doi.org/10.14201/eks2015162612.

[16] García-Peñalvo, F.J., Fidalgo Blanco, Á., and Sein-Echaluce Lacleta, M.L., 2014. Tendencias en los MOOCs. http://gredos.usal.es/jspui/handle/10366/125093.

[17] García-Peñalvo, F.J. and Seoane-Pardo, A.M., 2015. Una revisión actualizada del concepto de eLearning. Décimo Aniversario. Education in the Knowledge Society 16, 1, 119-144. DOI= http://dx.doi.org/http://dx.doi.org/10.14201/eks2015161119144.

[18] González-Rogado, A.B., Rodríguez-Conde, M.J., Olmos-Migueláñez, S., Borham, M., and García-Peñalvo, F.J., 2013. Experimental evaluation of the impact of b-learning methodologies on engineering students in Spain. Computers in Human Behavior 29, 2 (Mar), 370-377. DOI= http://dx.doi.org/10.1016/j.chb.2012.02.003.

[19] Liyanagunawardena, T.R., Adams, A.A., and Williams, S.A., 2013. MOOCs: A Systematic Study of the Published Literature 20082012. The International Review of Research in Open and Distance Learning 14, 3, 202-227.

[20] Martínez Abad, F., Rodríguez Conde, M.J., and García-Peñalvo, F.J., 2014. Evaluación del impacto del término "MOOC" vs "eLearning" en la literatura científica y de divulgación. Profesorado. Revista de currículum y formación del profesorado 18, 1, 185201.

[21] Mcmillan, J.H. and Schumacher, S., 2005. Investigación educativa. Pearson Educación, Madrid, España.

[22] Pappano, L., 2012. The Year of the MOOC. In The New York Times, New York.

[23] Pernías Peco, P. and Luján-Mora, S., 2014. Los MOOCS: Orígenes, historia y tipos. Comunicación y Pedagogía, $269-270,41-47$.

[24] República Del Ecuador, 2008. Constitución de la República del Ecuador Registro Oficial, Quito, Ecucador.

[25] Roig Vila, R., Mengual Andrés, S., and Suárez Guerrero, C., 2014. Evaluación de la calidad pedagógica de los MOOC. Profesorado. Revista de Currículum y Formación de Profesorado 18, 1, 27-41.

[26] Scolari, C.A., 2014. Title. In Hipermediaciones, https://hipermediaciones.com/2014/07/11/instrucciones-para-hacer-un-mooc/.

[27] Secretaría Nacional De Planificación Y Desarrollo, 2013. Plan Nacional para el Buen Vivir. Senplades, Quito, Ecuador.

[28] Seoane Pardo, A.M. and García-Peñalvo, F.J., 2014. Pedagogical Patterns and Online Teaching. In Online Tutor 2.0: Methodologies and Case Studies for Successful Learning, F.J. García-Peñalvo and A.M. Seoane Pardo Eds. IGI Global, Hershey, PA, 298-316. DOI= http://dx.doi.org/10.4018/978-1-4666-5832-5.ch015. 
[29] Seoane-Pardo, A.M., 2014. Formalización de un modelo de formación online basado en el factor humano y la presencia docente mediante un lenguaje de patrón. In Programa de Doctorado en Formación en la Sociedad del Conocimiento. Instituto Universitario en Ciencias de la Educación. Universidad de Salamanca, Salamanca, Spain. http://gredos.usal.es/jspui/handle/10366/123342.

[30] Stake, R., 2005. Investigación con estudios de caso. Morata, Madrid, España.

[31] Wilson, S., Liber, O., Johnson, M., Beauvoir, P., Sharples, P., and Milligan, C., 2007. Personal Learning Environments: Challenging the dominant design of educational systems Journal of e-Learning and Knowledge Society 3, 3, 27-38.

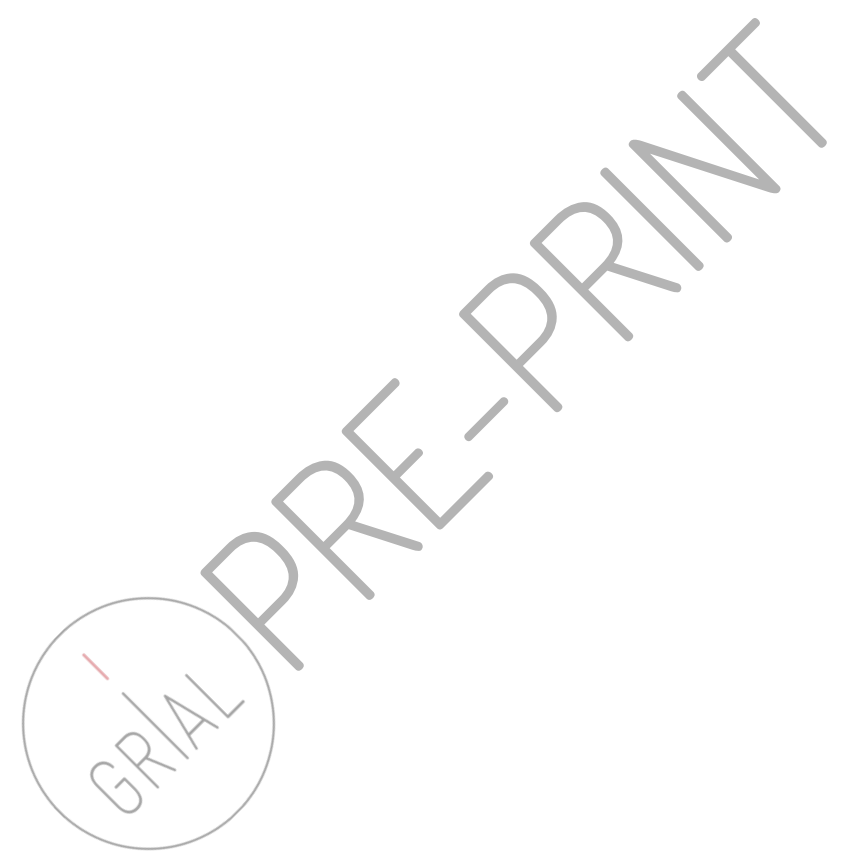

